\title{
Exploration on the Modes of Ideological and Political Education in Traditional Colleges and Universities from the We-media Perspective*
}

\author{
Wenhua Cai \\ School of Marxism \\ Chongqing Normal University \\ Chongqing, China 401331
}

\begin{abstract}
The network communication structure owned by We-media and the attributes and trends of decentration are opposite to the top-down vertical hierarchy of power distribution system in universities, which has resulted in the stripping of traditional analytical paradigms. Just as capital and labor will never move towards reconciliation, the discourse right of mainstream ideology in colleges and universities will always be challenged. But the application of ideological and political education can make its control logic strengthened and not go to ideological pluralism. The new media discourse mechanism created by the We-media era has found a balance between the theoretical logic and the realistic logic, which provides a perspective for the perfection of construction path of ideological and political education in colleges and universities.
\end{abstract}

Keywords-We-media; ideological and political education; ideology

\section{INTRODUCTION}

"We-media" is also known as "citizen media" or "personal media", which refers to the means by which the individual uses modern media, and a collective name of new mass media that disseminates information to individuals or the public in a "point to point" manner. Its network communication structure and the nature and trend of decentration enhance the discourse power of ordinary people rapidly. Under such a specific background, the individual is also the carrier of information dissemination, on which we can examine the nature of communication tools used in this era, such as blog, weibo, WeChat, forum /BBS and other online communities. It can bring about creativity, possibility and reform for ideological and political education in colleges and universities. Based on ideological and political education theory class, the public discourse space of traditional ideological and political education in colleges and Universities has more prominent contradiction with college students' medium speaking rights like We-media. The fragmentation and teasing of language forms when We-media disseminates information are more and more antagonistic to the ideological and political education in

*Fund project: "Using We-media to enhance the effectiveness of Ideological and political theory teaching in colleges and universities" of Research and Innovation Project of Graduate Students in Chongqing (CYS17187).

CLC number: G641 traditional universities that tends to be grand and rigorous. If the builders of ideological and political education in colleges and universities grasp this difference, it is conducive to understand the characteristics and psychological tendencies of contemporary college students and create new public discourse space to better carry out ideological and political education work.

\section{SYMBOLIC Form AND "SOCIAL ADHESIVE"}

\section{A. Reproduction of Symbolic Form: We-media}

"In all society, the generation and communication of symbolic forms - language statement, posture, action, art, have always been a universal feature of social life." [1]Nowadays, because of double accumulation after the combination of technology and capital, symbolic forms can be produced, exchanged and reproduced at an unprecedented speed. Mass media has been developed from the original newspapers and books as the main media to the information age, which takes the Internet as the main channel. This exponential growth has brought about the emergence of Wemedia and the distribution and exchange of information, which gradually deviates from the centralized and unified control of the ruling group and become a "subsidiary" of the subordinate group. "As of December 2017, the number of Internet users in China reached 772 million, with the popularity rate of $55.8 \%$. $4.1 \%$ more than the global average $(51.7 \%), 9.1 \%$ more than the average level of Asia (46.7\%). The total number of new Internet users increased by 40.74 million over the whole year, with the growth rate of 5.6\%. And the number of Internet users in China continued to maintain steady growth. [2]At present, with instant messaging tools, comprehensive social applications and vertical subdivision social applications as the main, the popularity and use of mobile terminals represented by mobile phones enable We-media to create a more completely new cultural context and behavior, which makes the whole society, especially the mainstream ideology discourse power of colleges and universities in China face the challenges of being constantly eroded, infiltrated and weakened. Colleges and universities as one of the forefront positions of ideological work, how they make good use of the media to integrate ideological education resources, is an 
important means for us to meet this challenge and guarantee Marx's guiding position in the ideological field of colleges and universities.

Since the construction and circulation of symbolic forms by We-media, people have entered the production and reproduction of information in a peer-to-peer manner, which has a certain impact on the communication structure of ideological and political education in colleges and universities. First, under the traditional mode of mass communication, the ideological and political education in colleges and universities has top-down communication characteristics. In addition to the attributes of universities itself, it is also subject to multiple restrictions of social system, capital and technology. The integration and reconstruction of traditional symbolic form by We-media is not to reduce the original information access threshold, or to seek another mechanism and mode of information production. This has divided the status of ideological discourse in colleges and universities, which gradually inclined to the object of ideological and political education as a subordinate position. As an audience, each individual can process, produce and exchange information as a medium and in a variety of formats, such as video, audio, image, and text. Two is the decentration of ideological work in colleges and universities. At this point, we have to make a clear premise that there is still a center at present. It is only a kind of decentralized nature and trend. Just like the block chain technology represented by bitcoin in the virtual money market, in the transmission of information, a point-to-point network propagation structure is derived. This structure is no longer centered with mainstream ideology and has the characteristics of data encryption.

\section{B. "Social Adhesive" and Vertical Power Structure}

In Ideology and Modern Culture, John. B.Thompson takes ideology as a "social adhesive", and this view is criticized in detail that mass communication is regarded as a particularly effective mechanism for the application of adhesive. That is to say, ideology is the cement needed for building walls, and mass communication is a good painter. He discarded such a flawed statement, and make an interpretation of ideology in its own way "I think the concept of ideology can be used to refer to the way in which special situations serve the establishment and support of asymmetrical power relations systematically. This power relationship is what I call "rule relations". [3]The ideological and political education in colleges and universities in China today is the traditional vertical power structure, which is regarded as a "social adhesive" for all audiences to share certain values. This kind of dialogism is firmly grasped and relied on a transcendental preaching of ideas, attitudes and attitudes, so that the mainstream ideology is lifted up high to build the gap between the private sphere and the public sphere. Its side effects are in two aspects, the first is the influence of western erroneous thoughts represented by historical nihilism on today's college students; the second is, all serious public discourse may be generalized by entertainment or even voluntarily become its appendage. Since the emergence of Wemedia as an interface, each university student as a node externalizes his speech in a moral narrative and irrational emotional resonance. When we debate the vertical power structure in the traditional paradigm, it is easy to be labeled "cent" or "fifty cents". Though it is thought that Qiu Shaoyun he was lying in the fire without moving violates physiological knowledge, it's just emotional exaggeration for ideological propaganda needs. In addition, this interface boosts the development of populism on the Internet. That is, in order to flow or click rate, we can entertain the things that should be seriously expressed.

\section{INTERPRETATION OF THE EDUCATION CONSTRUCTION OF IDEOLOGICAL POLITICS IN COLLEGES}

\section{A. Separation of Traditional Analysis Paradigm}

"The hegemony of a social group is manifested in the following two aspects: 'rule' and 'intellectual and moral leadership'... A social group must start exercising 'leadership' before gaining power (This is one of the first conditions to win the regime)."[4]This shows that the leadership group's right to speech is the only way to achieve class rule. And by making people identify with their ruling ideology, it becomes the soft power to realize social domination. This internal construction is different from the way to achieve class rule by means of violent organs, which is isomorphic to the work of ideological and political education in colleges and universities. "Colleges and universities shoulder the important mission of personnel training, scientific research, social services, cultural inheritance and innovation, international exchanges and cooperation ... Our party has always attached great importance to the ideological and political work in colleges and universities, and has explored a series of basic principles and regulations." [5]This shows that ideological and political education in colleges and universities is very important. But the traditional analytical paradigm is the top-down vertical power structure, which seems to be impracticable to sum up the principles and methods that should be followed in ideological and political education. So we stripped it (not abandoned), and the introduction of We-media has made the analysis paradigm plump which has tended to be flat. Ideological and political theory course is an important place for ideological and political education in colleges and universities. The emergence of We-media has changed the form of interaction in the modern ideological and political education classroom. And this new symbolic form is reflected in the most basic aspect for its intervention of the ideological and political education classroom. That is to say, the subject and object of education can communicate even without the same time and space background. Compared with the one-way flow of communication and communication in the past, this greatly enriches the way in which the education object assembles the ideas it accepts. Obviously, this contains the two levels of meaning: one is that We-media cannot be restricted by time and space, and it is possible to influence the thinking and behavior of objects in a more efficient way at a distance; two is the greater risk that the subject of education faces. Through the media, the educational subject can communicate with a large number of widely dispersed objects. They must be careful to express and explain their views. Because of the properties and trends of network structure and decentralization of We-media, the defects of various viewpoints conveyed by the educational subject will be exposed and magnified 
infinitely. And the point-to-point transmission method provides the possibility for educational objects to question such defects. Unilateral statements or improper behavior published by educational subjects will make them appear to be inadequate, shallow and loss in dominant role. This is a special vulnerability caused by the emergence of We-media. The result of this vulnerability may be that the education subjects gradually abandon the divergent views which are originally belonged to normal academic exchanges and tended to be conservative.

Judging from the actual operation of university organizations, ideological and political education is facing a state lack of publicity, which is reflected in two aspects: on the one hand, the imbalance between the hierarchical arrangement of power and the expression of rights. Colleges and universities tend to adopt a top-down leadership structure in terms of the balance between operational efficiency and teaching quality. The Party committees of colleges and universities exercise overall leadership over school work, which is the first echelon of power control; there are also heads of departments from various disciplines who form the second echelon; the ordinary teachers, students and various student autonomous organizations form the third echelon. The hierarchical control of this power is embodied in that, as the core of leadership in the cause of socialism with Chinese characteristics, our Party no matter from theory or practice should firmly occupy the leading position in the field of ideology. Only there may be a problem from management to control in practical practice, and the fundamental difference between them is whether students are treated as independent individuals. In order to reduce the operation cost of school organization life and improve the efficiency and quality of school organization life, the school management system takes control as the mainstream management and control mode. The power ranking control mentioned above is an addition to this governance logic. The management of student needs authority, which belongs to the internal certification of school organizational life. The control of students needs authority more. It comes from the vertical power structure from the top to bottom, whose most direct expression is taking the object of education as a machine. As controlled objects, students only need to learn the established textbook knowledge and master all kinds of examination skills. Observing disciplines, they have no right to question the emergence of these disciplinary norms. Moreover, it is impossible to negate its unreasonable provisions through some legal means, because this is not the result of dialogue and consultation between schools and students. When students appear independent ideas and want to participate in the management system of the school, it is found that there is a public atmosphere that has no democratic discussion; on the contrary, they are regarded as dissimilar to the mainstream ideology. And this is not conducive to the realization of goal of ideological and political education in schools. If schools insist on management as an enterprise or factory to manage such a path of alienation governance, just as labor and capital can never be reconciled. The network communication structure of We-media and the attributes and trends of decentration will bring trouble to the construction of ideological and political education in colleges and universities.

\section{B. Influence of "We-media" on the Construction of Ideological and Political Education Work in Colleges and Universities}

New media represented by We-media has tributaries outside the mainstream ideology because of its convenience and interaction. Theoretically, it belongs to the valuation process of symbolizing form in the specific historical context. And the symbolic value is to evaluate its value by producing or receiving its individual. From the ancient to the present, no matter what kind of social form, because of the limitations of existing objective conditions, it is impossible to show that a certain value system is common to all people, but there are differences between the mainstream and the periphery. In the media age where symbolic forms are mainly one-way communication, the mainstream ideology has been strengthened with the development of mass communication. But in the media era, this strengthening effect is not so obvious. The main manifestations are as follows:

First, the cognitive confusion caused by the westernization of college students' thoughts. During the process that the development of We-media has been accompanied by socialist modernization, the industrial accumulation for many years in western countries have bred a large number of excellent books on natural science and social sciences. The essence of introducing such works in Chinese universities is actually the integration of modern culture. In the field of humanities and social sciences, all kinds of "Western ideas" are produced, which have also been entered into China as the name of reform. The conflict to mainstream ideology in universities is manifested by the distinguishing confusion between university students' modernization and "Westernization". The social trend of thought mainly based on historical nihilism, Neo liberalism, populism and universal value theory, is parasitic in college students' thoughts in various ways, such as they think political multiparty competition, wanton slander and discredit of historical heroes, the idea of universal suffrage replacing the people's congress system and completely free competitive market economy is reasonable. For this type of ideological trend, we can make a good judgment of its irrationality based on whether it accords with the laws of social and historical development. When this kind of ideological trend spreads to the life practice of university students due to the interactive characteristics of We-media, its significance in serving power (weakening or enhancing) is what we want to discuss in the second point.

Second, it will weaken the existence of cultural selfconfidence. When the Western civilization which originated in the industrial revolution mingled with the traditional Chinese civilization, it has become the representative of modern civilization to a certain extent. And this can be seen in real life in the process of modeling. If most young people marry, they should use a diamond ring (the product of Western Civilization) to prove love, or take the pluralistic value in the ideological field for granted. Because of the extensiveness of symbolic forms, the sequelae to our college students are that they regard western culture and values as a criterion, and regard Chinese traditional culture as a straw. It provides the soil for the contradiction between the Westernization of individual spirit and the constraint of state's feelings. To a certain extent, this is 
due to the spontaneity of market. As Sandel said, "one of the defects of society driven market is that it will make the virtues of altruism, generosity, solidarity and civic spirit lose vitality." [6]However, it should be noted that this is only a very small phenomenon with a trend of alienation.

\section{THE EFFECT OF WE-MEDIA IN TRADITIONAL} IDEOLOGICAL AND POLITICAL EDUCATION IN COLLEGES AND

\section{UNIVERSITIES}

"In order to achieve a great dream, a great struggle must be carried out. The society is advancing in the contradictory movement, and there will be struggle if there is contradiction." [7]Strengthening ideological and political education in colleges and universities is an important part of realizing the great dream.

\section{A. Using We-media to Strengthen the Dominant Power of Discourse}

The symbolic media mentioned above, the top-down vertical structure of power structure in colleges and universities, and the network structure of We-media and the property and trend of decentration, belong to the objective existence of today's society. The content of ideological and political education in colleges and universities belongs to the content of social consciousness. If the theoretical logic between them is inconsistent with our objective logic, there will be a state of imbalances. Thus, this state will be absorbing all kinds of ideology without distinction. The dialectical principle of historical materialism tells us that this discrepancy will always exist along with the development of human history. Before the political socialization of our college students, we can use the dominant position of discourse to correct this discrepancy. In order to strengthen the discourse dominance in ideological and political work in colleges and universities, we should restore the imbalance. We can use We-media as a tool in its operation mode.

In the field of application of We-media, the symbolic media leads to the visualization, fragmentation and entertainment of information content itself. In the era of big data, "private customization" enables individuals to act according to their preferences in the process of production and consumption culture, and make the group psychological performance more prominent. The grand narrative used by the mainstream ideology has been shunted in comparison with the realistic characteristics of We-media. And the former only flows to a specific group and has little attraction to the public. Therefore, for the value concept dominated by the ideological and political workers in colleges and universities, when it is expressed in a symbolic form acceptable to the public, it is easier for people to accept and believe, so as to become group morality. When it evolves into group morality, our discourse dominance - just like the public service provided by the government is universally accepted - has been strengthened again.

Then it integrates multiple values in unity. "It is possible to construct a unified form at the symbolic level. People are included in the collective identity rather than their differences, so as to establish and support the rule of relations. A typical strategy for representing this pattern in symbolic form is standardization. [8]To a certain extent, it answers the question why our country cannot be diversified in the ideological field. The "Chinese dream" to realize the great rejuvenation of Chinese nation is to construct a unified form to create a sense of belonging. When the ideological and political educators intertwine the narrative process of history, reality and future with the ideological construction of contemporary college students through We-media, the significance produced by the collision between unitary and pluralism, order and disorder, and individuals and groups within this framework is the consolidation of dominant position of the discourse.

\section{B. The Education Path Develops from One-way Linear Narrative to Multi-dimensional Structure}

"Since We-media has the characteristics of individuation, equality and openness, it greatly liberates the media's right to speak and provides a new platform for expressing views and gathering opinions." [9]It also provides us with a propaganda place. This place, if not be occupied by our ideological and political workers in colleges and universities, will be occupied by others. The traditional ideological and political education in colleges and universities takes the ideological and political theory classroom as the main position. And the public discourse space formed by the educational subject's linear narrative of educational content can no longer meet the actual needs. The emergence of We-media has provided a new media discourse mechanism for college students. From BBS forum of universities at the dawn of the Internet, to nowadays "two Wei and one end" (micro-blog, WeChat, mobile clients) are the carriers of this new media discourse mechanism. The new public discourse space constructed by the constructors of ideological and political work in colleges and universities on the basis of this carrier. To a certain extent, we have reconstructed our ideological and political education - this is not a change in the nature of education. It is the multi dimension of educational path, thus changing the practice of communication between subject and object in traditional public space.

\section{CONCLUSION}

The influence of media's iterative upgrading to the current era of We-media has penetrated into all aspects of life. The mode of ideological and political education in colleges and universities is inevitably affected. And the key is to identify how it affects the construction of ideological and political education in colleges and universities. The first part of this paper focuses on the relationship between symbolic form and We-media and why it is not advisable to compare ideological and political education with "social adhesive". The second part discusses the traditional mode of ideological and political education in colleges and universities, and analyzes the problems existing in the ideological and political education work in colleges and universities with the vertical power distribution structure as the main. And it also analyzes the impact by introducing We-media. Finally, it tries to answer the instrumental application of We-media in the construction of ideological and political education in colleges and universities from two aspects. 


\section{REFERENCES}

[1] John.B.Thompson. Ideology and Modern Culture [M]. translated by Gao Xian, etc, Beijing: Yilin Press, 2012: 1.

[2] The 41st China Internet Development Statistics Report [J]. China Radio, 2018(03):96.

[3] John.B.Thompson. Ideology and Modern Culture [M]. translated by Gao Xian, etc, Beijing: Yilin Press, 2012: 3, 7.

[4] Antonio Gramsci, Prison Notebooks [M]. translated by Cao Leiyu, Beijing: China Social Sciences Publishing House, 2000: 292

[5] Opinions on Strengthening and Improving Ideological and Political Work in Colleges and Universities under New Situation issued by the Central Committee of the Communist Party of China[N]. People's Daily, 2017-02-28(001).

[6] Sander. What Money Can't Buy [M]. translated by Deng Zhenglai, Beijing: China Citic Press. 2012: 144.

[7] Xi Jinping, Remain true to our original aspiration and keep our mission firmly in mind, hold high the banner of socialism with Chinese characteristics, secure a decisive victory in building a moderately prosperous society in all respects, strive for the great success of socialism with Chinese characteristics for a new era, and work tirelessly to realize the Chinese Dream of national rejuvenation. Delivered at the 19th National Congress of the Communist Party of China, 2017.

[8] John.B.Thompson. Ideology and Modern Culture [M]. translated by Gao Xian, etc, Beijing: Yilin Press, 2012: 71-72.

[9] Yan Fangjie. Analysis of Media Discourse Mechanism of College Students in the Era of We-media [J]. Ideology Education, 2015,(04):7882. 